\title{
RELIGIOUS INTERSECTIONS IN AFRICAN CHRISTIANITY: THE CONVERSION DILEMMA AMONG INDIGENOUS CONVERTS
}

Joel Mokhoathi

Religion Studies

University of the Free State

\begin{abstract}
The conversion of indigenous converts to Christianity is often perceived as a linear process, which marks individuals' rebirth and assumption of a new identity as they are assimilated into the Christian fold. This simplistic view, however, seems to undermine the intrinsic technicalities that are involved in the process of conversion, particularly for indigenous converts who already embrace a unique worldview, which is different from and sometimes contradictory to the conservative Christian outlook. This paper uses a qualitative research approach in the form of document analysis to critically explore the religious intersectionalities between Christianity and African Traditional Religion (ATR), and discusses some dilemmas that are inherent in the conversion of indigenous converts. It concludes by suggesting a paradigmatic model for re-viewing and reinterpreting the coming together of Christianity and African Traditional Religion in Africa south of the Sahara, particularly in South Africa.
\end{abstract}

Keywords: African Christianity; African traditional religion; conversion; indigenous converts; hybridity

\section{Introduction}

Conversion, as a transformative process, does not occur in a vacuum (Masondo 2015:93). It is significantly influenced by the "interplay of identity, politics and morality" (Hefner 1993:4). That is why social scientists continue to show interest in the notion of conversion, especially Christian conversion, as a religious experience that solidifies faith and transforms the believer's life (Staples and Mauss 1987:146). This is because conversion implies "the acceptance of a new locus of self-definition, a new, though not necessarily exclusive, reference point for one's identity" (Hefner 1993:17). This paper, therefore, critically explores the religious intersectionalities between Christianity and African Traditional Religion (ATR), and discusses some dilemmas which are inherent in the conversion of indigenous converts. A paradigmatic model according to which the intersection between Christianity and ATR can be understood and interpreted, is also suggested. This paradigmatic model rests upon the premise of hybridity rather than syncretism as a popular concept.

\section{The intersection of Christianity and ATR}

The developed awareness that Christianity in Africa, particularly in South Africa, has generally been merged with African Traditional Religion, does not seem to excite, and 
tends to generate some agitation in both conservative Christians and rigorist African religionists. The central consensus between these two religious traditions is that Christianity and ATR are a paradox and cannot therefore be reconciled (Mndende 2009:8). This perception, however, appears to controvert the nominalist view, which advocates that the two religious traditions - Christianity and ATR - are compatible and are, in fact, two related systems of thought and practice (Mlisa 2009:8). These erratic perceptions therefore appear to ground understanding and interpretation of the intersectionalities between Christianity and ATR.

In most cases, these interpretations tend to be absolute and often seem to undermine the insider view - the views of the practitioners. This means that both conservative Christians and rigorist African religionists tend to see a clear divide between Christianity and ATR, but nominal Christians often allude to a grey area, which is not necessarily acknowledged or explored by non-practitioners. In their view, Christianity and ATR are two related systems of thought and practice (Hirst 2005:4).

The opponents of this nominalist view argue that this intersection implies syncretism (Bediako 1994:14). Thus, it is argued that the syncretism of Christianity and ATR distort the originality of both systems, since the elements of one religion are expressed through the other (Hastings 1989:30-35).

What is often undermined in this debate, however, is the evaluation of how Christianity made its way into Africa. According to Ferguson (2003:115), Bosch (1991:227) and Oduro, Pretorius, Nussbaum and Born (2008:37), Christianity arrived in Africa riding on the wings of colonisation and Western civilisation.

Therefore, subversion, potency and military strength were part of this crusade (Reill and Wilson 2004:294). African converts were often obligated to accept Christianity (Chingota 1998:147). Their religious and cultural heritage was ridiculed and commonly classified as heathenism (Carey 1792:93; Brown 1970:3). They were forced to acknowledge Christianity, as early missionaries were set on destroying their cultural and religious heritage (Hoschele 2007:262). The external pressure which Christianity imposed upon the structural functioning of their society was so great that it could not simply be ignored (Mlisa 2009:9). They had to adapt, and juxtaposing Christianity and ATR was an alternative way of doing so.

\section{Critiquing the intersectionality - Christianity and ATR}

Initially, the intersectionality of Christianity and ATR appears to have grown out of the missionary error of not recognising the value of African traditional customs and religious systems (Willoughby 1970: xviii-xix). However, its endurance so far, even after the missionary pressure has ended, seems to beg an enquiry. It makes one wonder how this phenomenon moved beyond the stages of pretense (if it was ever used to garner social recognition, acceptance and material gains from missionaries), to a level where indigenous converts willfully and purposely prefer to juxtapose Christianity and ATR.

Could this be a new form of expression which African converts were denied during the missionary epoch, which is now manifesting in the form of the intersectionality between Christianity and ATR? Or is it the basic search for a true African Christian identity, which is generated by the search for a way in which one may truly be an African Christian within an African cultural context? If this realism is indeed a search for an Afro-Christian identity, then it is comprehensible. African Christians must try to find 
Religious Intersections in African Christianity: Conversion Dilemma among Indigenous Converts 3

ways in which they may fully express their Christian identity within their cultural context.

If this comes about by trial and error, then it is also sensible - as long as they discover themselves in the process. But if this is a new form of expression, then one must enquire how this realism is lived, and how the practitioners of this reality describe it. An inside view is therefore imperative in this form of enquiry. But since this paper deals with the technicalities inherent to the conversion of indigenous converts, this inquiry will be reserved for another time.

Some scholars, however, feel that the intersection of Christianity and ATR is a form of hypocrisy, in which African people use Christianity and its symbols to revive their religious practices (De Gruchy 1990:46). But other scholars, such as Ray (1976:3), see this as an account of ignorance. Indigenous converts had no alternative means by which to resisthe influence of Christianity other than incorporating Christian values systems into their African traditional belief systems (Mbiti 1969:223). They sought to acknowledge the Christian influence without denying their cultural identity. Mugambi (2002:519-520) notes that "[o]n the one hand, they [indigenous converts] accepted the norms introduced by the missionaries who saw nothing valuable in African culture. On the other hand, the converts could not deny their own cultural identity". This implies that indigenous converts were often put in a position where they had to choose between denominational belonging and cultural identity.

Their dilemma is clear, "[t]hey could not substitute their denominational belonging for their cultural and religious heritage. Yet they could not become Europeans or Americans merely by adopting some aspects of the missionaries' outward norms of conduct" (Mugambi 2002:519-520). A reasonable solution to this dilemma was to juxtapose the two religious traditions - Christianity and ATR. This, however, was not an easy process. It required that African converts live double lives: They professed to be Christians in public but were also supporters of ATR in private (Ntombana 2015:110).

They lived this double life because early missionaries forbade them from practicing their African traditional rites and customs (Afeke and Verster 2004:50). Those who were found contravening the regulations of the missionaries were harshly and publicly disciplined (Mills 1995:153ff). Elaborating on this idea, Ntombana (2015:110) notes that in 1881 the Wesleyan Methodist clerics James Lwana and Abraham Mabula were disciplined for accepting Lobola (dowry) for their daughters. Another Methodist cleric, Nehemiah Tile, was found guilty of contributing an ox for the circumcision of the Tembu paramount heir, Dalindyebo. After this incident, Nehemiah Tile is said to have withdrawn from the Methodist Church (Mills 1995:153ff). This indicates that the missionary campaign was hostile towards the African cultural and religious heritage. It sought to replace traditional norms with Western cultural values (Jafta 2011:61). That is probably why scholars such as Prozesky (1991:39) note that:

It is important for Christians to remember that in the experience of black people, the gospel arrived here in tandem with deeply destructive political and commercial forces which have succeeded in making two of South Africa's indigenous faiths, those of the Khoikhoi and the San, extinct within our boarders, have destroyed all the once-independent polities of the pre-European period and massively exploited 
all their survivors, and have extensively eroded the ancestral faiths of the Bantuspeaking peoples.

Therefore, when critiquing the intersectionality between Christianity and ATR, scholars ought to consider the historical context from which this realism was born: It is the direct consequence of the supremacy of Christianity over indigenous religions in Africa. As Lado (2006:8) contends, Christianity was ethnocentric. It was characterised by the dominance of Western culture over African cultures. This ethnocentric attitude elevated the status of Christianity, but at the expense of indigenous religions - such as ATR.

Indigenous religions, like those of the Khoikhoi and San, were massively undermined and ultimately extinguished (Prozesky 1991:39). The spirituality of indigenous people was seen as barbarism or heathenism (Bediako 1992:225). Their conversion to Christianity was viewed as a form of "liberation from a state of absolute awfulness [...]." (Hastings 1967:60). But, as Ray (1976:3) contends, these early missionary perceptions of African people were "based on inaccurate information and cultural prejudice".

Early missionaries should have attempted to understand the cultural and religious context of indigenous people. William (1950:15) appears to have understood the importance of this compromise:

The evil of institutions "often lies on the surface while the good only becomes apparent as the result of prolonged and painstaking investigation": but "the more a missionary knows his people, the more he finds to admire" and marvel at even in the lowliest forms of religion. It is impossible to regard the religious systems of savage and barbarous peoples as merely the work of the devil.

This implies that early missionaries hastily judged the embodiment of African traditional cultures and religious systems without proper, prolonged or painstaking investigation. As a result, they basically rejected a great number of African ideals and traditional customs. Yet scholars such as Mugambi (2002:517) note that Christianity cannot be fully expressed or adequately communicated without a cultural medium. This implies that Christianity can find expression in any cultural medium, including the African culture. In this manner indigenous converts should be allowed to experience Christianity or Christ within their cultural context.

\section{Conversion as a dilemma for indigenous converts}

The conversion of indigenous converts to Christianity is often seen as a linear process that marks the rebirth of an individual into the new faith and is characterised by the assumption of a new identity. But this simplistic view tends to undermine the intrinsic details inherent to the conversion of people who already possess a unique worldview, which is based on the rationality of the African traditional religious heritage and its socio-cultural norms. This worldview is different from, and sometimes appears to contradict, the conservative Christian view. The conservative Christian outlook ${ }^{1}$ places

The phrase "conservative Christian outlook" is used in this paper to refer to Christians who tend to follow conservative values, in contrast to liberal Christian viewpoints. The label "conservative", however, does not necessarily imply the acceptance of all basic conservative values. Rather, it designates Christian groups who are more traditional than other members of the same faith family. 
Christ at the centre of everything, whereas the ancestors play a dominant role in the African traditional worldview.

Conversion, as the "transformation of one's self concurrent with a transformation of one's basic meaning system" (McGuire 2002:73), either consolidates or challenges these worldviews. This implies that conversion has the ability to reinforce or challenge the sense of who people are and their sense of belonging within a social setting. This happens to be the case with radical transformation. Radical transformation occurs when people make a radical change through conversion to a different religious tradition and when this change affects both their self-actualisation and social affiliations (McGuire, 2002:74).

A clear example of this is when a Muslim person converts to mainstream Christianity, or vice versa, through marriage. This form of conversion has both the ability to change the sense of who people are and their sense of belonging within the social context. This is because the new identity often demands that people break away from their old or previous identity in order to fully submerge themselves within the current. This break away from the old identity may easily bring about some form of alienation from their previous community, as their new identity no longer aligns with their former way of life and traditional beliefs.

Therefore, the conversion of indigenous converts who are practitioners of ATR to Christianity has the same drastic implications for the converting individuals. They often feel obliged to break with their old self or previous identity in order to fully submerge themselves within the new Christian identity, thereby running the risk of being alienated from their traditional communities. William (1950:4), a former Bishop of Masasi in Tanzania (1926-1944), describes this dilemma as follows:

The new Christian rises from the waters of the font and goes back to his home in the village with his fellow tribesmen, men of his own nation and race: what is to be the practical relation between the new life and the old? As a catechumen he has tried to face it, but now, white from the laver of regeneration, it comes home to him with a new urgency, how shall he walk worthy of the vocation wherewith he is called? In grace he has come into a new society, his life has been raised to a new plane. But though no longer of the world, he is still in the world: he has to live out his faith in everyday life. Again and again situations will arise in which he may easily imperil his soul's new health. Custom will demand his participation with his relatives and kindred in much of which he may feel a real distrust, and yet, if he refuses to be associated with his fellow tribesmen in what are regarded as essential acts of citizenship and duties to the community, he begins to be in danger of cutting himself off completely, and at the end becoming an outcast. If his own tribe into which he was born no longer recognizes him, it is impossible for him to become a real member of any other tribe or people. He can indeed do his best to imitate the ways of another race, and another race may do their best to offer him comradeship and make him their associate to the utmost extent to which this is possible; but more than an associate he cannot become.

This denotes that, for indigenous converts, converting to Christianity often gave rise to the damning concern of breaking away from their former identity and thereby incurring the possibility of social denunciation. Thus, no matter how much indigenous converts 
sought to live up to Christian principles or may have embraced western precedence, when judged according to social norms and communal expectations, they quickly gained the status of outcasts. They were obligated to choose between their former lives and their new Christian identity.

If they refused to be associated with their fellow tribesmen in what was regarded as essential acts of citizenship and duties to the community, they were in danger of cutting themselves off completely from their tribes (William 1950:4). The "[t]raditionalists understood such an act as betrayal because it meant the rejection of traditional customs and practices" (Masondo 2015:94). In agreement with this, Hastings (1994:61) observes that "[i]n the nineteenth century Christian converts tended by and large to be ex-slaves, outcasts from their society, [and] refugees looking for a safe haven".

These converts were seen as amambuka (traitors), or amagqobhoka ${ }^{3}$. In order to deal with such demands of identity loss and social denunciation, William (1950:4-5) notes that indigenous converts often considered two options:

[E]ither he will come to the missionary and ask for guidance, what he may do and what he may not do; or, if his conscience is only barely awakened or his faith has not led to a true conversion of heart, he will acquiesce too easily in the ways of the old life and lapse from religion, behaving at times as barely more than a baptized heathen, losing his sonship in slavery to the old life.

According to this first option, the indigenous convert would go to the missionaries for guidance on "what to do" or "what not to do". This involved the verbal transmission of Christian teachings and ethical guidelines (Ray 1976:5). In order to demonstrate their commitment and sincerity to the new Christian faith, they were expected to make public declarations of faith and had to exchange their indigenous names for Christian ones. According to Ntombana (2015:109), Christian names like "John, Joseph and Timothy" were given to them to reflect their new Christian identity. They were also expected to uphold all the principles and values of western culture - such as education, clothing, behaviour, etc. They were kept under close scrutiny not to disobey the teachings and guidelines of the missionaries (Matobo, Makatsa and Obioha 2009:15). Those who appeared to contravene the teachings and guidelines of the missionaries were suspended from the church (Ray 1976:5). They were "only allowed back to the Church after undergoing the church ritual of repentance and cleansing, which included public confession and assurance that they would not do it again" (Ntombana 2015:109).

This made some indigenous converts choose the second option - "acquiescing too easily in the ways of the old life and lapsing from religion [Christianity], behaving at times as barely more than a baptized heathen, losing his sonship in slavery to the old life" (William, 1950:5). This so-called "lapsing from religion" was characterised by the

Among amaZulu tribes, Christian converts were referred to as amambuka (traitors) because they were seen to be rejecting the ways of their forefathers, as well as their community. They literally ran away and settled in mission stations (see Sibusiso Masondo 2015:94).

3 Among amaXhosa tribes, a Christian convert was referred to as igqobhoka. This term has no direct translation into English. But Mndende (1998:9) describes igqobhoka as a container with a hole in it, that is letting out what is good and valuable, while letting in what is evil and undesirable. She argues that amagqobhoka are untrustworthy because they serve two masters - Christ and the ancestors. 

secret practice of ATR with its rites and customs (Mathema, 2007:5; Mbiti, 1992:264). This is because early missionaries did not take the initiative to familiarise themselves with the traditional forms in which the religious sense of their converts was embodied (Sanneh, 1993:15; Schineller, 1990:6). Rather, they encouraged these Christian converts to break with their religious and socio-cultural heritage.

Willoughby (1970:xix) rightly states that "[t]o cut a man completely away from the heritage that his ancestors left him, the mental and spiritual environment of his earlier years, would be to sever him from all that he has hitherto held sacred". In order to avoid this form of alienation from the heritage of their ancestors, indigenous converts resorted to the secret practice of the ATR. As Mndende (2009:1) remarks, they resolved to "sit on the fence", becoming Christians in public, but supporters of ATR in private. This gives the impression that indigenous converts were pressured into incorporating Christian values systems into their African religious and socio-cultural value systems.

These effects, however, are usually less drastic with consolidation (McGuire 2002:74). Consolidation is another form of conversion which entails the consolidation of an already existing identity and its meaning system with another similar religious identity. For instance, this happens when a Roman Catholic church member converts to an Anglican church member. These two religious traditions are similar and convey corresponding systems of meaning and belief. In this regard, consolidation does not challenge, but re-enforces identity.

But among indigenous converts to Christianity, the most common form of conversion is radical conversion which radically challenges the way they perceive themselves and their personal belonging within their society. In order to avoid this form of disorder, indigenous converts often tended to intersect Christianity and ATR, thereby blending the two religious systems.

This two-way process of blending and borrowing from one religious tradition to another is generally perceived as "hybridity" (Spielmann 2006:1). The process of hybridisation is by nature unapologetic and intentional (Müller 2008:1), whereas that of "syncretism" tends to suggest "the blending of foreign, non-Christian elements with (putatively 'pure', 'authentic') Christian beliefs and practices” (McGuire 2008:189).

\section{Hybridisation as a developing paradigmatic model}

The concept of religious "hybridity" is an ingenious metaphor to describe the African religious discourse. This is because the concept of hybridity denotes the socio-cultural exchange of various traditions from one group to the other (Bohata 2004:129). Scholars such as Spielmann (2006:1) note that "[h]ybridity has become a term commonly used in cultural studies to describe conditions in contact zones where different cultures connect, merge, intersect and eventually transform".

Hybridisation therefore denotes "the two-way process of borrowing and blending between cultures, where new, incoherent and heterogeneous forms of cultural practices emerge in translocating places - so-called third spaces" (Spielmann 2006:1). Cieslik and Verkuyten (2006:78) further note that hybridity is "predominantly used to describe cultural phenomena and identities", and this paradigmatic approach is relevant to the study of indigenous cultures.

Unlike Cieslik and Verkuyten (2006:78), who emphasise that hybridity refers "to the different lifestyles, behaviours, practices and orientations that result in multiple 
identities", I prefer Spielmann's description (2006:1) of hybridity as "a term [that is] commonly used in cultural studies to describe conditions in contact zones where different cultures connect, merge, intersect and eventually transform", because the coming together of various cultural traditions does not automatically imply the assumption of multiple identities, as Cieslik and Verkuyten (2006:78) suggest.

But hybridity can denote the consolidation of identity by incorporating or supplementing certain external components of culture which do not fully find adequate expression within the immediate cultural tradition. Therefore, the notion of hybridity features strongly where two or more cultural or religious traditions intersect and result into an altogether new hybrid. Homi Bhabha (1994: 211) describes this process in the following manner:

[T] he importance of hybridity is not to be able to trace two original moments from which the third emerges, rather hybridity [...] is the "third space" which enables other positions to emerge. This third space displaces the histories that constitute it, and sets up new structures of authority, new political initiatives, which are inadequately understood through received wisdom.

African Christians often fall into this category. They often espouse their African worldviews to supplement their Christian beliefs. For instance, cultural elements like witchcraft, oohili/thokolosi ${ }^{4}$, or ukuthwetyulwa ${ }^{5}$, are often undermined by mainstream Christianity, whereas these are taken seriously in African religion. Prayers are sometimes simply not enough to protect people against these, so they use charms or fetishes as additional means of protection. These protective elements do not find an interpretive paradigm within the Christian context, hence it is often difficult for Christians to understand the dynamics of African spirituality and mysticism. They cannot easily tap into African worldviews, which exist outside the scope of the Christian system, in order to understand these dynamics.

Thus, some traditional components of African cosmology are essential and necessary for African Christians to supplement the expression of Christianity within the African context. Fasholé-Luke (1978:366), for instance, notes that African theologians have begun to demonstrate "that the African religious experience and heritage were not illusory, and that they should have formed the vehicle for conveying the Gospel verities to Africa". These theologians argue that it is the rehabilitation of the African cultural and religious heritage that may regain the self-respect of Africans (Fasholé-Luke 1978:366).

Some African scholars strongly argue that in this reconstructive process the coming together of Christianity and ATR should not be categorised as "syncretism" (Mokhoathi 2017:4-5). This is because many Christian theologians still consider the dialogue between Christianity and ATR as a step towards syncretism (Adamo 2011:16). According to this perception the syncretising of Christianity and ATR denotes the corruption of Christianity. On the other hand, the notion of hybridity seems "to evoke an

\footnotetext{
4 There is no direct translation of this term into English. But oohili/thokolosi may be described as dwarf-like creatures that are used by witches to pursue evil ends, or to cause harm to other people, including their enemies.

5 There is no direct translation of this term into English. But ukuthwetyulwa may imply abduction through witchcraft to alien places, such as forests, rivers, deserts, or mountains, while family members assume that the victim has died.
} 

unapologetic sense of blending, whereby two different traditions contribute in roughly equal measure to a new cultural/religious product" (Müller 2008:1).

I am of the opinion that this is where constructive dialogues should be based with regards to the merging between Christianity and ATR. African Christians must be empowered to find ways in which to authentically express and experience their Christian identity within their cultural context. This should evoke an unapologetic sense of blending, whereby two different traditions - the Christian and the African - contribute in equal measure to facilitate a new socio-cultural and religious end product. This end product, however, should be measured against and founded on solid biblical hermeneutics, which uphold scriptures as the standard critique of culture and its traditional practices.

In this sense, no cultural traditions which contravene the authoritative voice of scriptures, no matter how viable, may be considered or acknowledged. The scriptures must serve as a filter for indigenous customs and practices that may produce a conducive environment for African converts to experience Christianity within their cultural context. The seamless model of hybridity therefore appears to be a constructive paradigm in which to base and interpret the coming together of Christianity and ATR.

\section{Conclusion}

It is clear that conversion, as a transformative process, does not occur within a vacuum. Rather, it occurs within a socio-cultural and/or religious context as a result of which the converting individual already possesses a particular worldview. This worldview may be consistent with or different from (and sometimes contradictory to) the new worldview being undertaken. The conversion of indigenous converts to Christianity often mirrors the latter rather than the former situation. The former refers to the consolidation of identity through conversion, whereas the latter pertains to the alteration of identity through radical transformation. Radical conversion has the ability to drastically challenge the way converts perceive themselves and how they belong in society, thereby giving rise to issues such as identity crises or internal conflicts. These are inherent complexities of conversion. Against this background, the linear approach, which tends to characterise conversion as rebirth and the assumption of a new identity, seems to be too simplistic. It tends to undermine the dilemmas that are inherent in the conversion of indigenous converts. This is because the old identity often does not dissipate but tends to be incorporated into the new Christian identity. Therefore, this form of intersectionality is complex and needs to be re-evaluated. Hence a new paradigmatic model, which is based on the premise of hybridity, may be useful for the exploration of such an intersectionality.

\section{BIBLIOGRAPHY}

Adamo, D.T. 2011. Christianity and the African Traditional Religion(s): The postcolonial round of engagement, Verbum et Ecclesia 32:1-10.

Afeke, B. and Verster, P. 2004. Christianisation of ancestor veneration within African Traditional Religions: An evaluation, In die Skriflig 38(1):47-61. 
Bediako, K. 1992. Theology and identity: The impact of culture upon Christian thought in the Second Century and modern Africa. Oxford: Regnum Books International.

Bediako, K. 1994. Understanding African theology in the 20th Century, Themelios 20:14-20.

Bhabha H. 1994. The location of culture. London: Routledge Publications.

Bohata, K. 2004. Post-colonialism revised: Writing Wales in English. Cardiff: University of Wales Press.

Bosch, D.J. 1991. Transforming mission: Paradigm shifts in mission theology. Maryknoll: Orbis Books.

Brown, W.H. 1970. On South African frontier: The adventures and observations of an American in Mashonaland and Matabeleland. New York: Negro University Press.

Carey, W. 1792. An enquiry into the obligations of Christians, to use means for the conversion of the heathens. Didcot, Oxfordshire: Baptist Missionary Society.

Chingota, F. 1998. A historical account of the attitude of Blantyre Synod of the Church of Central Africa Presbyterian towards initiation rites. In James L. Cox (ed.), Rites of passage in contemporary Africa: Interaction between Christian and African Traditional Religions. Cardiff, UK: Cardiff Academic Press, pp. 146-55.

Cieslik, A. and Verkuyten, M. 2006. National, ethnic and religious identities: Hybridity and the case of the Polish Tatars, National Identities 8(2):77-93.

De Gruchy, J.W. 1990. The church struggle in South Africa. Grand Rapids, Michigan: William B. Eerdmans Publishing Company.

Fashole-Luke, E.W. 1978. Christianity in independent Africa. London: R. Collings Publications.

Ferguson, N. 2003. Empire: How Britain made the modern world. London: Allen Lane Publications.

Hastings, A. 1976. African Christianity. London: Geoffrey Chapman.

Hastings, A. 1989. African Catholicism - An essay in discovery. London: SCM Press. Hastings, A. 1994. The church in Africa 1450 - 1950. New York: Oxford University Press.

Hefner, R.W. 1993. Introduction: World building and the rationality of conversion. In Robert. W. Herfer (ed.), Conversion to Christianity: Historical and anthropological perspectives on a great transformation. Oxford: University of California Press, pp. 3-46.

Hirst, M.M. 2005. Dreams and medicines: The perspective of Xhosa diviners and novices in the Eastern Cape, South Africa, Indo-Pacific Journal of Phenomenology 5:1-22.

Höschele, S. 2007. Christian remnant - African folk church: Seventh-day Adventism in Tanzania, 1903-1980. Boston, MA: Brill Publication.

Jafta, L. 2011. The Methodist Church of Southern Africa: The establishment and the expansion of the mission. In Itumeleng Mekoa (ed.), The journey of hope: Essays in honour of Dr. Mmutlanyane Stanley Mogoba. Cape Town: Incwadi Press, pp. $56-65$.

Lado, L. 2006. The Roman Catholic Church and African religions: A problematic encounter, The Way 45:7-21.

Masondo, S. 2015. Indigenous conceptions of conversion among African Christians in South Africa, Journal for the study of Religion 28(2):87-112. 
Mathema, Z.A. 2007. The African worldview: A serious challenge to Christian discipleship, Ministry, International Journal for Pastors 79:5-7.

Matobo, T.A, Makatsa, M. and Obioha, E.E. 2009. Continuity in the traditional initiation practice of boys and girls in contemporary Southern African society, Studies of Tribes and Tribals 7:105-13.

Mbiti, J.S. 1969. African religions and philosophy. London: Heinemann Educational Books.

Mbiti, J.S. 1992. African religions and philosophy (rev. ed.). London: Heinemann Educational Books.

McGuire, M.B. 2002. Religion: The social context. London: Wadsworth Thomson Learning.

McGuire, M.B. 2008. Lived religion: Faith and practice in everyday life. Oxford: Oxford University Press.

Mills, W.G. 1995. Missionaries, Xhosa clergy and the suppression of traditional customs. In C. Bredenkamp and Robert J. Ross (eds), Missions and Christianity in South African history. Johannesburg, RSA: Witwatersrand University Press, pp. 153-72.

Mlisa, N.L. 2009. Ukuthwasa, the training of Xhosa women as traditional healers. $\mathrm{PhD}$ dissertation, University of the Free State.

Mndende, N. 2009. Tears of distress: Voices of a denied spirituality in a democratic South Africa. Dutywa, RSA: Icamagu Institute.

Mokhoathi, J. 2017b. From contextual theology to African Christianity: The consideration of adiaphora from a South African perspective, Religions 8(266):114.

Mugambi, J.N.K. 2002. Christianity and the African cultural heritage. In Jesse N.K. Mugambi (ed.), Christianity and African culture. Nairobi: Acton Publications, pp. $516-42$.

Müller, R. 2008. Rain rituals and hybridity in South Africa, Verbum et Ecclesia JRG 29(3):819-31.

Ntombana, L. 2015. The trajectories of Christianity and African ritual practices: The public silence and the dilemma of mainline or mission churches, Acta Theologica 35:104-19.

Oduro, T., Pretorius, H., Nussbaum, S. and Born, B. 2008. Mission in an African way: A practical introduction to African instituted churches and their sense of mission. Wellington: Christian Literature Fund and Bible Media Publication.

Prozesky, M. 1991. The challenge of other religions for Christianity in South Africa, Journal of Theology for Southern Africa 74:35-45.

Ray, B.C. 1976. African religions: Symbol, ritual and community. Englewood Cliffs, New Jersey: Prentice-Hall Inc.

Reill, P.H. and Wilson, E.J. 2004. Encyclopedia of the Enlightenment. New York: Facts On File Incorporated.

Sanneh, L. 1993. Encountering the West: Christianity and the global cultural processthe African dimension. Maryknoll, New York: Orbis Books.

Schineller, P. 1990. A handbook on inculturation. New York: Paulist Press.

Spielmann, H. 2006. Hybridity: Arts, science and cultural effects, Leonardo 39(2):2339. 
Staples, C.L. and Mauss, A.L. 1987. Conversion or commitment? A reassessment of the Snow and Machalek approach to the study of conversion, Journal for the Scientific Study of Religion 26(2):133-47.

Stromberg, P.G. 2008. Language and self-transformation: A study of the Christian conversion narrative. Cambridge: Cambridge University Press.

William, V. 1950. Christianity and native rites. London: Central Africa House Press.

Willoughby, W.C. 1970. The soul of the Bantu: A sympathetic study of the magicoreligious practices and beliefs of the Bantu tribes of Africa. Westport, Connecticut: Negro University Press. 